\title{
PELATIHAN JAVASCRIPT UNTUK GAME CANVAS DI LINGKUNGAN SMK
}

\author{
Kartiko Ardi Widodo' ${ }^{1}$, Suryo Adi Wibowo ${ }^{2}$, Yosep Agus Pranoto ${ }^{3}$ \\ Teknik Elektro, Institut Teknologi Nasional Malang ${ }^{1}$ \\ Teknik Informatika, Institut Teknologi Nasional Malang ${ }^{2}$ \\ e-mail: tiko_ta@yahoo.com ${ }^{1}$, oryusdee@gmail.com ${ }^{2}$, lusaryku@yahoo.com ${ }^{3}$
}

\begin{abstract}
Abstrak - Saat ini mitra adalah salah satu SMK swasta yang merupakan pilihan favorit warga kota Malang. Salah satu kebutuhan yang akan dibantu pada kegiatan ini adalah bantuan sumber daya manusia untuk persiapan kegiatan LKS pada bidang desain grafis dengan aplikasi grafis yang harus ditanamkan dalam website dikarenakan dalam kurikulum nasional untuk SMK topik ini masih belum ada. Solusi yang ditawarkan pada mitra adalah dengan melakukan short course yang ditujukan pada mitra dengan peserta guru dan siswa dengan materi terkait desain grafis dengan aplikasi grafis yang harus ditanamkan dalam website. Kontribusi pada khalayak berupa short course yang ditujukan pada mitra dengan peserta guru dan siswa dengan materi terkait desain grafis dengan aplikasi grafis yang harus ditanamkan dalam website.
\end{abstract}

Kata kunci : SMK, Short Course, Website

Abstract - Currently, the partner is one of the private vocational schools (SMK) which is the favorite choice of Malang city residents. In this regard, the activity provided is human resource assistance for the preparation of LKS activities in the field of graphic design with graphic applications embedded in the website. The need for this topic is essential for the school since the current curriculum has not covered it yet. The solution was offered to partners (both teachers and students as participants), giving them materials related to graphic design using graphic applications embedded in the website. Contribution to the public in the form of short courses aimed at partners with teacher and student participants with material related to graphic design with graphic applications that must be embedded in the website.

Keywords : SMK, Short Course, Website

\section{PENDAHULUAN}

Kota pendidikan adalah salah satu julukan yang melekat pada kota Malang. Julukan ini muncul lantaran banyaknya jumlah kampus dan sekolah yang ada di Malang raya. Terdapat setidaknya lebih dari 80 Perguruan Tinggi yang tersebar di wilayah Malang Raya. Jumlah perguruan tinggi yang sebanyak itu lah sehingga akhirnya banyak mahasiswa dari luar kota memenuhi kota Malang untuk menuntut ilmu. Namun ternyata julukan kota Pendidikan itu telah muncul jauh lebih lama sebelum terbentuknya kampus-kampus yang ada sekarang. Pada masa Hindia Belanda, Malang sudah memiliki puluhan sekolah yang tersebar di segala penjuru. Jumlah itu termasuk sangat banyak untuk kota dengan luas dan jumlah penduduk seperti Malang. Pertumbuhan jumlah sekolah yang sangat pesat ini, terjadi pada kisaran tahun 1914-1939.

Dukut Imam widodo, dalam bukunya yang berjudul Malang Tempo Doeloe menyebut bahwa pada tahun 1914, di Malang baru ada delapan sekolah saja. Delapan sekolah tersebut terdiri dari 1 MULO (sekolah lanjutan atau setingkat SMP), 3 ELS (Sekolah dsar dengan sistem Eropa), 1 HCS 
(Sekolah dasar khusus etnis tionghoa), dan 3 Inlands Scholen der 2e Klasse (Sekolah dsar pribumi atau biasa disebut sekolah ongko loro). Namun jumlah itu meningkat sangat pesat pada sekitar tahun 1930-an. Pada saat itu jumlah sekolah yang sebelumnya hanya delapan, meningkat pesat menjadi puluhan jumlahnya. Meningkatnya perekonomian dan bertambahnya penduduk kota Malang secara pesat menjadi alasan semakin banyak munculnya sekolah. Sebagian sekolah yang ada di masa lalu tersebut, hingga kini bangunannya masih ada dan tetap digunakan sebagai sekolah. Beberapa yang masih ada adalah HBS dan AMS di jalan Tugu yang kini jadi SMA Negeri 1,3, dan 4 Malang, serta beberapa kompleks sekolah lain seperti Santo Yusuf, Cor Jesu, dan Frateran yang bangunannya telah berdiri sejak zaman Hindia Belanda. Karena statusnya yang memang sebagai kota pendidikan sejak masa lalu, tentu saja sudah banyak pelajar dari kota lain yang bersekolah di Malang. Rata-rata mereka berasal dari wilayah sekitar Jawa Timur dan tinggal di asrama yang dikelola sekolah atau kos di daerah sekitar sekolah. SMK Nasional malang merupakan sekolah tertua dan tertangguh di kota Malang, didirikan pada tanggal 17 Juli 1951 merupakan bukti nyata, bahwa sampai dengan saat ini SMK Nasional Malang masih dipercaya oleh masyarakat sehingga dari tahun ke tahun memiliki siswa yang bertambah banyak. SMK Nasional Malang terletak di jantung kota Malang tepatnya di jalan Raya Langsep No 43, dengan lokasi yang strategis terletak di tepi jalan besar yang mudah diakses oleh kendaraan pribadi atau pun umum yang merupakan pilihan tepat dan bernilai ekonomis bagi siswanya

Saat ini mitra adalah salah satu SMK swasta yang merupakan pilihan favorit warga di kota Malang untuk menyekolahkan anaknya, sekolah SMK ini memiliki jurusan teknik Informatika yang menjadi favorit kedua setelah jurusan mesin. Permasalahan yang muncul pada mitra adalah mitra SMK ini memiliki keinginan untuk mengikuti kegiatan lomba yang terkait desain grafis dengan aplikasi grafis yang harus ditanamkan dalam website, akan tetapi dalam lomba tersebut memiliki tantangan salah satunya pembuatan desain grafis dengan aplikasi grafis yang harus ditanamkan dalam website tersebut.sedangkan SDM yang dimiliki sekolah tersebut masih kesulitan untuk saat ini dalam memberikan materi tersebut kepada siswa,dikarenakan materi tersebut masih belum ada pada kurikulum nasional untuk SMK .

Berdasarkan permasalahan yang telah dipaparkan pada sub bab sebelumnya, maka dapat dilakukan identifikasi masalah sebagai berikut :

1. Kemampuan siswa pada sekolah mitra yang dipersiapkan sebagai peserta dianggap masih belum mampu untuk dapat bersaing dalam menghadapi LKS.

2. Peserta yang dipersiapkan untuk mengikuti LKS hanya satu orang.

3. Peserta yang dipersiapkan oleh mitra dalam menghadapi LKS juga diprioritaskan untuk menghadapai lomba lainnya.

4. Peserta yang dipersiapkan oleh mitra dalam menghadapi LKS dan lomba lainnya adalah siswa kelas XII, yang tentunya juga harus mempersiapkan diri dalam Ujian Nasional untuk menentukan kelulusan.

5. Keputusan kelulusan Ujian Nasional pada SMK Mitra, tidak dipengaruhi oleh pretasi lomba yang pernah diikuti oleh siswa. 
6. Tenaga pengajar pada mitra masih belum memiliki keterampilan yang mumpuni dalam kasus Game Canvas menggunakan Javascript.

7. Tenaga pengajar pada mitra masih belum mempersiapkan modul ajar untuk persiapan LKS.

8. Budaya siswa pada sekolah mitra yang masih dianggap belum layak untuk mengikuti lomba sekelas LKS.

9. Pada sekolah mitra, siswa dianggap mampu dalam suatu materi apabila siswa tersebut telah dapat meniru. Hal ini dianggap masih tidak layak untuk maju ke pertandingan.

Berdasarkan identifikasi masalah yang telah disebutkan pada sub bab sebelumnya, maka dapat dirumuskan masalah sebagai berikut :

1. Bagaimana membuat Short Course yang ditujukan pada mitra agar mampu bertanding dalam menghadapi LKS?

2. Bagaimana membuat modul pembelajaran yang mudah dipahami dalam waktu singkat untuk siswa pada sekolah mitra tentang pemrograman Canvas menggunakan Javascript yang ditanamkan pada website, sesuai tema LKS yang dipilih oleh mitra yang diadakan oleh Kementerian Pendidikan dan Kebudayaan (Kemendikbud)?

\section{METODE PENGABDIAN}

Langkah-langkah dalam melaksanakan solusi yang ditawarkan untuk mengatasi permasalahan mitra dijelaskan sebagai berikut :

1. Permasalahan dalam bidang sosial pendidikan

SMK Mitra merupakan salah satu sekolah kejuruan milik swasta yang beroperasi di kota malang. Di tengah persaingan yang semakin ketat, sekolah ini juga tidak kalah dengan sekolah kejuruan lainnya. Dengan terus meningkatkan prestasi baik dalam bidang akademik maupun non akademik, baik prestasi yang dicetak oleh staff, karyawan dan guru maupun prestasi yang dicetak oleh siswa. Salah satu kompetisi yang bergengsi adalah Lomba Kompetensi Siswa atau yang dikenal dengan LKS yang diselenggarakan oleh Kemendikbud yang secara konsisten sejak tahun 1992 hingga saat ini. Kementerian Pendidikan dan Kebudayaan (Kemendikbud) terus mendorong dan memberikan motivasi kepada para siswa Sekolah Menengah Kejuruan (SMK) dalam meningkatkan kompetensi, dan menanamkan karakter positif yang diwujudkan dalam pelaksanaan Lomba Kompetensi Siswa (LKS) SMK tingkat nasional, dengan 51 bidang yang diperlombakan. Dalam pengembangannya, LKS saat ini sudah masuk pada tingkat internasional dengan melibatkan Negara-negara ASEAN yang tergabung dalam South East Asia Creative Camp (SEACC). Acara tahunan ini ternyata membuat berbagai sekolah kejuruan di seluruh Indonesia dijadikan sebagai acara bergengsi untuk meningkatkan popularitas dan kualitas sekolah di mata masyarakat. Hal ini juga dijadikan sebagai media promosi yang dapat menjual nilai sekolah di mata masyarakat, sehingga dapat memberikan pengakuan terhadap lulusan SMK. Tidak ketinggalan juga untuk SMK Nasional, Kota Malang. Namun untuk menghadapi kompetisi semacam ini diperlukan persiapan yang matang. Target SMK pada Lomba Kompetensi Siswa (LKS) tahun 2020 adalah dapat lolos wilayah kerja 3. Sayangnya resource yang dimiliki oleh sekolah dalam hal ini yang dimaksud adalah guru, dianggap masih belum mampu untuk membimbing siswanya dalam menghadapi kompetisi tersebut. Berdasarkan informasi yang didapatkan dari wawancara dengan 
guru yang ditunjuk sebagai guru pendampng, menyatakan bahwa materi yang diujikan pada LKS melebihi kurikulum SMK. Begitu juga untuk pemilihan siswa yang akan dikirim untuk menjadi peserta LKS, mengingat hanya ada satu siswa yang akan mewakili sekolah dalam LKS. Untuk dapat memilih siswa yang dianggap mampu untuk dibina atau diajukan untuk mengikuti pelatihan dalam menghadapi LKS, pihak mitra menganggap yang mampu dan memenuhi kualifikasi tersebut hanyalah siswa yang duduk di kelas XII. Hal ini dianggap sangat mengganggu bagi siswa, karena siswa kelas XII sedang mempersiapkan diri untuk ujian nasional. Permasalahan ini dianggap serius oleh pihak mitra. Di satu sisi sekolah menginginkan untuk unggul dari yang lainnya dengan alasan salah satu cara promosi, disisi lain siswa yang dipersiapkan hanya seeikit yang memiliki kualifikasi untuk dapat mengikuti LKS. Oleh karena itu, mitra dalam hal ini adalah SMK Nasional, Kota Malang mengirimkan permohonan kepada Prodi Teknik Informatika S1, ITN Malang dalam kegiatan bimbingan untuk mengahadapi Lomba Kompetensi Siswa (LKS) pada akhir tahun 2019.

2. Partisipasi mitra dalam pelaksanaan program

Bentuk partisipasi mitra dalam kegiatan bimbingan untuk menghadapi Lomba Kompetensi Siswa (LKS) yaitu :

a. Mitra mempersiapkan (memilih) siswa yang memiliki kemampuan yang dianggap mampu atau memenuhi kualifikasi dalam persiapan pelatihan atau pembimbingan untuk mengikuti LKS. Siswa tersebut akan mengikuti proses pelatihan yang dilaksanakan di Prodi Teknik Informatika S1, ITN Malang.

b. Mitra mempersipkan atau menunjuk guru pendamping, dan akan mengikuti proses pelatihan yang dilaksanakan di Prodi Teknik Informatika S1, ITN Malang.

3. Evaluasi pelaksanaan program dan keberlanjutan program di lapangan setelah kegiatan PKM selesai dilaksanakan.

Evaluasi yang dilaksanakan oleh tim pengabdi dimaksudkan untuk mengetahui apakah tahapan proses yang diterapkan sudah baik atau belum. Tahapan ini dilakukan dengan cara memberikan kuisioner kepada mitra tentang kinerja tim pengabdi. Dan diskusi antar tim pengabdi tentang kendala apasajakah yang dialami selama melakukan proses pengabdian ini. Keberlanjutan program pelatihan di lapangan dilakukan dengan memberikan bekal materi pelatihan dalam bentuk modulyang khusus dipersiapkan untuk menghadapi LKS, sehingga baik siswa maupun guru pendamping dapat mempelajarinya dengan mudah. Pihak mitra juga bermaksud untuk bekerjasama dengan Prodi Teknik Informatika untuk dapat memberikan pelatihan kembali dalam menghadapi Lomba Kompetensi Siswa (LKS) di tahun mendatang.

\section{WAKTU DAN TEMPAT PENGABDIAN}

Lokasi mitra pengabdian masyarakat bertempat di alamat Jl. Raya Langsep 43 Malang, Jarak: $12,9 \mathrm{~km}$. Kondisi lingkungan kegiatan pengabdian masyarakat seperti ditunjukkan pada Gambar 1. 


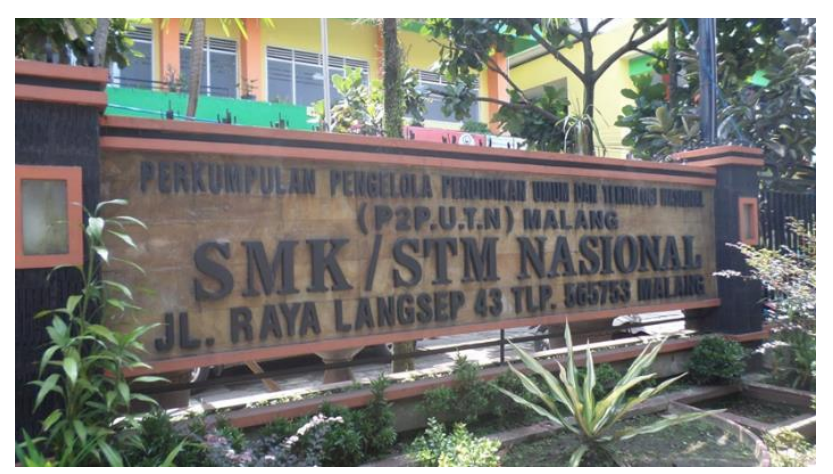

Gambar 1. Kondisi lingkungan lokasi pengabdian masyarakat.

\section{KERANGKA PEMECAHAN MASALAH}

Secara umum kerangka pemecahan masalah dapat digambarkan dalam metode pelaksanaan yang digunakan pada pengabdian masyarakat ini dengan mengadakan pelatihan yang meliputi teori dan praktek yang berkaitan dengan desain grafis dengan aplikasi grafis yang harus ditanamkan dalam website. Adapun kerangka pemecahan masalah dalam pengabdian kepada Masyarakat ini meliputi beberapa tahapan, yaitu survei tentang pemanfaatan materi ajar dan kesesuaian kurikulum, perancangan materi pelatihan, pembuatan modul pelatihan, pelaksanaan pelatihan, evaluasi, sehingga para guru dan siswa mampu mengaplikasikan modul Desain Grafis. Kerangka pemecahan masalah ditunjukkan seperti Gambar 2.

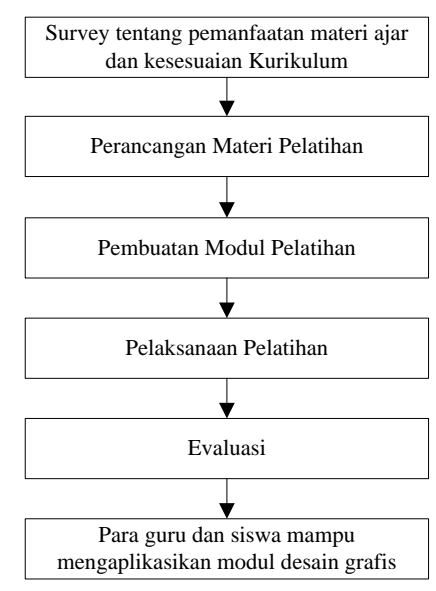

Gambar 2. Kerangka Pemecahan Masalah

\section{KERANGKA EVALUASI}

Rancangan evaluasi digunakan untuk mengetahui apakah Short Course yang telah dilakukan dapat memberikan nilai manfaat terhadap mitra. Dalam hal ini rancangan evaluasi dilakukan terhadap mitra yaitu siswa, guru dan terhadap kepala sekolah yang dapat diberikan penjelasan sebagai berikut :

a. Rancangan evaluasi yang dilakukan terhadap siswa dilakukan dengan cara memberikan simulasi lomba pada setiap akhir pertemuan materi dengan menggunakan timer sesuai materi yang telah dipelajari pada pertemuan tersebut. Dalam proses ini siswa tidak diperkenankan 
untuk mencontek atau membuka catatan dalam bentuk apapun. Di akhir Short Course, siswa melakukan simulasi final LKS sesuai dengan tema yang telah dipilih menggunakan kisi-kisi yang LKS pada tahun sebelumnya dan menggunakan timer. Proses simulasi final ini ini dilakukan sebanyak 2 kali.

b. Rancangan evaluasi yang dilakukan terhadap guru pengajar mata pelajaran terkait pada sekolah mitra yaitu dilakukan dengan cara diskusi dan memberikan kuesioner kepada guru terhadap cara mengajar kepada siswa oleh tim pengabdi selama proses pembelajaran Short Course dalam menghadapi LKS. Tim pengabdi juga memberikan materi yang dianggap perlu dimasukkan dalam kurikulum materi pelajaran sekolah.

c. Rancangan evaluasi yang dilakukan terhadap kepala sekolah, yaitu dengan diskusi dan memberikan kuisioner cara mengajar kepada siswa oleh tim pengabdi selama proses pembelajaran short course dalam menghadapi LKS, serta ketepatan materi yang diberikan oleh tim pengabdi dalam menghadapi LKS.

\section{HASIL DAN PEMBAHASAN}

Proses pembelajaran Short Course dibuat seolah menyenangkan namun tetap dapat tercapai targetnya, seperti pada Gambar 3.

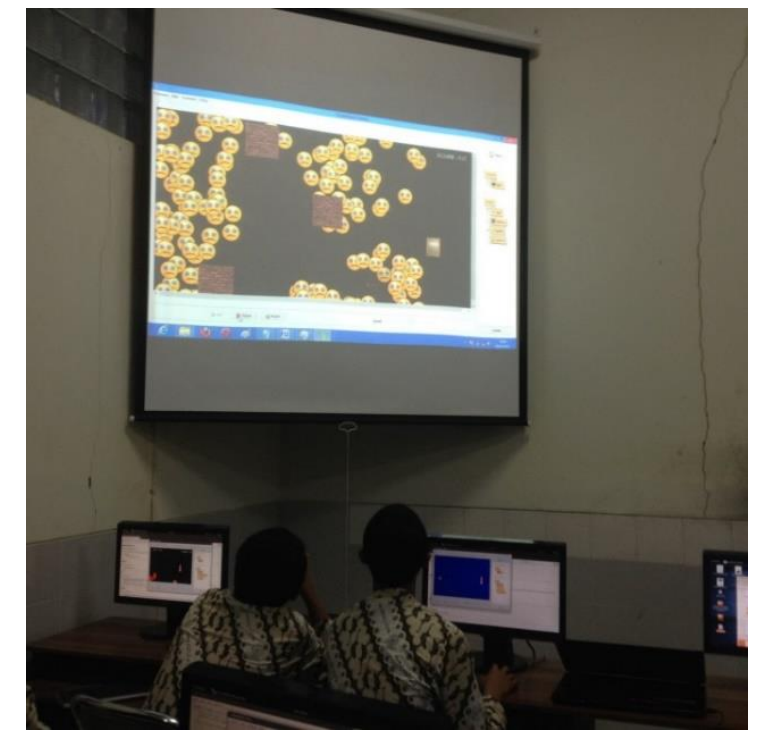

Gambar 3. Proses pengabdian kepada masyarakat

\section{HASIL PENGUJIAN SEBELUM DILAKUKAN PELATIHAN}

Untuk mengetahui kemampuan siswa pada mitra sebelum dilakukan Short Course, tim pengabdi melakukan proses pra-evaluasi, yaitu dengan cara memberikan kuisioner kepada 4 siswa pada sekolah mitra yang berisi soal umum mengenai pemahaman website. Materi soal praevaluasi tersebut merupakan materi dasar pemrograman web. Hal ini dimaksudkan untuk mengukur kemampuan siswa baik sebelum dan sesudah proses Short Course, dan didapatkan hasil seperti ditunjukkan Tabel 1. 
Tabel 1. Hasil pra-evaluasi

\begin{tabular}{|c|c|c|c|c|c|c|}
\hline \multirow{2}{*}{ No. } & \multirow{2}{*}{ Pertanyaan } & \multicolumn{5}{|c|}{ Penilaian } \\
\hline & & SB & B & $\mathrm{C}$ & $\mathrm{K}$ & SK \\
\hline 1. & $\begin{array}{l}\text { Bagaimana pemahaman Anda tentang website } \\
\text { ? }\end{array}$ & & 4 & & & \\
\hline 2. & $\begin{array}{l}\text { Bagaimana pemahaman Anda tentang } \\
\text { Javascript? }\end{array}$ & & 4 & & & \\
\hline 3. & $\begin{array}{l}\text { Apakah Anda dapat membangun website } \\
\text { sederhana? }\end{array}$ & & 4 & & & \\
\hline 4. & Apakah Anda dapat membangun Javascript? & & 4 & & & \\
\hline 5. & $\begin{array}{l}\text { Bagaimana pemahaman Anda tentang Object } \\
\text { Oriented Programming }(O O P) ?\end{array}$ & & 3 & 1 & & \\
\hline 6. & $\begin{array}{l}\text { Apakah Anda dapat membangun website } \\
\text { dengan konsep Object Oriented } \\
\text { Programming }(O O P) \text { ? }\end{array}$ & & 3 & 1 & & \\
\hline 7. & $\begin{array}{l}\text { Bagaimana pemahan Anda tentang Game } \\
\text { Canvas? }\end{array}$ & & 3 & 1 & & \\
\hline 8. & $\begin{array}{l}\text { Apakah Anda pernah membangun Game } \\
\text { Canvas berbasis website? }\end{array}$ & & 4 & & & \\
\hline 9. & $\begin{array}{l}\text { Apakah Anda dapat membangun website tanpa } \\
\text { mencontek dalam bentuk apapun? }\end{array}$ & & 2 & 2 & & \\
\hline 10. & $\begin{array}{l}\text { Apakah Anda dapat membangun Javascript } \\
\text { tanpa mencontek dalam bentuk apapun? }\end{array}$ & & & 4 & & \\
\hline 11. & $\begin{array}{l}\text { Apakah Anda dapat membangun website } \\
\text { dengan konsep Object Oriented Programming } \\
(O O P) \text { tanpa mencontek dalam bentuk apapun } \\
?\end{array}$ & & & 4 & & \\
\hline
\end{tabular}

Keterangan :

SB : Sangat Baik

B : Baik

C : Cukup

$\mathrm{K}$ : Kurang

SK : Sangat Kurang

Berdasarkan pengujian pra-evaluasi diperoleh hasil sebesar 70,4\% siswa peserta Short Course mampu memahami pemrograman website dasar dengan baik, namun dengan mencontek. Ketika diberikan pertanyaan nomor 9,10,11 siswa peserta Short Course menyatakan 99\% siswa kurang mampu dalam membangun website tanpa menggunakan contekan dalam bentuk apapun. Padahal point ini menurut tim pengabdi dianggap paling crusial. Namun hal ini masih perlu dibuktikan dengan proses simulasi 
LKS dengan menggunakan timer dan soal sesuai kisi-kisi yang diberikan. Karena untuk dapat bersaing dalam kompetisi LKS, siswa harus memiliki kemampuan mahir.

\section{HASIL PENGUJIAN SETELAH DILAKUKAN PELATIHAN}

Untuk mengetahui kemampuan siswa pada mitra setelah dilakukan Short Course, tim pengabdi melakukan proses post-evaluasi, yaitu dengan cara memberikan kuisioner kepada 4 siswa pada sekolah mitra yang berisi soal mengenai pemahaman website. Materi soal postevaluasi tersebut merupakan materi pemrograman web sesuai kisi-kisi LKS yang diberikan. Hal ini dimaksudkan untuk mengukur kemampuan siswa baik sebelum dan sesudah proses Short Course, dan didapatkan hasil seperti ditunjukkan Tabel 2.

Tabel 2. Hasil post-evaluasi

\begin{tabular}{|c|l|c|c|c|c|c|}
\hline \multirow{2}{*}{ No. } & \multicolumn{1}{|c|}{ Pertanyaan } & \multicolumn{3}{|c|}{ Penilaian } \\
\cline { 2 - 6 } 1. & $\begin{array}{l}\text { Bagaimana pemahaman Anda tentang } \\
\text { website? }\end{array}$ & 4 & & & & SK \\
\hline 2. & $\begin{array}{l}\text { Bagaimana pemahaman Anda tentang } \\
\text { Javascript? }\end{array}$ & 4 & & & & \\
\hline 3. & $\begin{array}{l}\text { Apakah Anda dapat membangun website } \\
\text { sederhana? }\end{array}$ & 4 & & & & \\
\hline 4. & $\begin{array}{l}\text { Apakah Anda dapat membangun } \\
\text { Javascript? }\end{array}$ & 4 & & & & \\
\hline 5. & $\begin{array}{l}\text { Bagaimana pemahaman Anda tentang } \\
\text { Object Oriented Programming (OOP)? }\end{array}$ & 3 & 1 & & & \\
\hline 6. & $\begin{array}{l}\text { Apakah Anda dapat membangun website } \\
\text { dengan konsep Object Oriented } \\
\text { Programming (OOP)? }\end{array}$ & 3 & 1 & & & \\
\hline 7. & $\begin{array}{l}\text { Bagaimana pemahan Anda tentang Game } \\
\text { Canvas? }\end{array}$ & 3 & 1 & & & \\
\hline 8. & $\begin{array}{l}\text { Apakah Anda pernah membangun Game } \\
\text { Canvas berbasis website? }\end{array}$ & 4 & & & & \\
\hline 9. & $\begin{array}{l}\text { Apakah Anda dapat membangun website } \\
\text { tanpa mencontek dalam bentuk apapun ? }\end{array}$ & 2 & 2 & & & \\
\hline 10. & $\begin{array}{l}\text { Apakah Anda dapat membangun } \\
\text { Javascript tanpa mencontek dalam } \\
\text { bentuk apapun? }\end{array}$ & 3 & 1 & & & \\
\hline 11. & $\begin{array}{l}\text { Apakah Anda dapat membangun website } \\
\text { dengan konsep Object Oriented } \\
\text { Programming (OOP) tanpa mencontek } \\
\text { dalam bentuk apapun? }\end{array}$ & 3 & 1 & & & \\
\hline
\end{tabular}

Keterangan :

SB : Sangat Baik

B : Baik

C : Cukup

$\mathrm{K}$ : Kurang 
SK : Sangat Kurang

Berdasarkan pengujian post-evaluasi diperoleh hasil sebesar 84,09\% siswa peserta Short Course mampu memahami pemrograman website dasar dengan sangat baik tanpa mengunakan contekan dalam bentuk apapun. Hal ini dibuktikan ketika diberikan pertanyaan nomor 9,10,11 siswa peserta Short Course menyatakan 99\% siswa Sangat Mampu dalam membangun website tanpa menggunakan contekan dalam bentuk apapun. Dari hasil tersebut maka dapat ditarik kesimpulan bahwa terdapat peningkatan kemampuan siswa pada mitra sebesar 13,63\% mengenai kemampuan pemrograman web, sehingga dianggap layak untuk maju sebagai peserta LKS.

\section{KESIMPULAN}

Kegiatan pengabdian kepada masyarakat telah selesai dilaksanakan. Berdasarkan kegiatan tersebut maka dapat ditarik kesimpulan sebagai berikut :

1. Berdasarkan pengujian yang dilakukan pada pra-evaluasi dan post-evaluasi, diketahui bahwa terjadi peningkatan keahlian dalam pemrograman web dalam membangun game Canvas menggunakan javascript sebesar 13,63\%.

2. Modul pembelajaran Short Course dapat digunakan oleh guru pengampu mata pelajaran website sebagai media pendukung pada proses belajar mengajar di sekolah.

\section{UCAPAN TERIMAKASIH}

Ucapan diberikan kepada LPPM ITN Malang sebagai penyandang dana abdimas ini.

\section{DAFTAR PUSTAKA}

Betha Sidik, (2018). Pemrograman Javascript Untuk Aplikasi Web. INFORMATIKA.

G ,Lu, F.A.P. Petitcolas (1999). Multimedia Database Management System, Artech House Publishers.

K, Sayood. (2000). Introduction to Data Compression. Morgan Kaufman.

S, Katzenbeisser. (2000). Information Hiding Techniques for Steganography and Digital Watermarking. Artech House Publishers

W3schools. (2020, June 5). HTML Canvas Tutorial. Diambil kembali dari w3scholls: https://www.w3schools.com/graphics/canvas_intro.asp

W, C Hardy. (2001). QoS Measurement and Evaluation of Telecomunication Quality of Service. Wiley.

WILLIAMS, James Lamar. (2012). Learning html5 game programming: A hands-on guide to building online games using Canvas, SVG, and WebGL. Addison-Wesley Professional.

Ze-Nian Li, Mark, S. Drew. (2003). Fundamentals of Multimedia. Prentice Hall. 